\title{
EDITORIAL
}

\section{A Time of Change}

Time changes alL things, but there are times when change crowds in upon us at an unaccustomed pace. Such a time has come to this Journal, and we must record with regret the retirement from the Editorial Board of three of its original members who were prime movers in bringing the publication into existence. In each case the decision to resign from the Board forms a part of a general reduction of the individual's commitment to professional responsibilities, looking towards retirement.

Dr. Leon Longtin asked in the spring of 1974 to be relieved of his responsibilities to the Journal, coincident with his retirement from the University of Montreal. For twenty years he had accepted responsibility for the French language summaries and for reading and correcting the French language page proofs. We acknowledge the great debt which the publication owes to Dr. Longtin for his long and dedicated service. In leaving he has ensured the future of these affairs by enlisting the services of Dr. Bernard Paiement of Montreal to continue them.

Dr. E.A. (Ted) Gain of Edmonton and Dr. André Jacques of Quebec were members of the group of young anaesthetists who, in 1953, persuaded their colleagues that Canadian anaesthetists should have their own Journal. In the intervening years, as members of the Editorial Board, they have made a distinguished contribution to the growth and quality of the publication. Their enthusiasm and sage advice has been greatly valued by all their colleagues. Dr. Gain and Dr. Jacques will be succeeded on the Editorial Board by Dr. Kenneth Leighton of Vancouver, and Dr. Marcel Boulanger of Montreal.

R.A. Gordon

\section{EDITORIAL}

\section{LES TEMPS CHANGENT ...}

LE TEMPS CHANGE TOUTES choses ... mais il y a des époques où ces changements nous bousculent de façon inaccoutumée. Notre Journal vit aujourd'hui une telle époque et il nous faut voir partir du Comité de Rédaction, trois des membres fondateurs de notre revue.

Pour chacun d'eux, ce départ s'inscrit dans un mouvement de dégagement graduel à l'égard des responsabilités professionnelles dans l'optique d'une retraite éventuelle.

A l'occasion de sa retraite de l'université de Montréal, le docteur Léon Longtin a demandé au printemps de 1974, d'ètre relevé de ses fonctions au Journal.

Durant vingt ans, il fut, tout compte fait, le rédacteur français de la revue, traduisant les résumés d'articles, lisant, évaluant, éditant les textes soumis en français. Pour cette infatiguable fidélité, le docteur Longtin mérite toute notre gratitude. Il n'a pas voulu partir sans assurer la relève; à sa demande, le docteur Bernard Paiement de Montréal, assurera dorénavant les mêmes services.

Les docteurs E.A. (Ted) Gain et André Jacques étaient pour leur part de ce 
groupe de jeunes anesthésistes qui en 1953 persuadèrent leurs collègues que les anesthésiologistes canadiens se devaient de publier leur propre Journal.

Au cours des années écoulées, leur travail au Comité de Rédaction a grandement contribué à la croissance et la maturation de notre revue. Leurs collègues évaluent hautement leur enthousiasme et leur sagacité.

Les docteurs Gain et Jacques seront suivis au Comité de Rédaction par les docteurs Kenneth Leighton de Vancouver et Marcel Boulanger de Montréal.

R.A. Gordon 